\title{
Assessing Teamwork Value in Project-Based Learning of Capstone Project Course
}

\author{
Nurshafiza Ismail $^{1 *}$, Nabilla Afzan Abdul Aziz ${ }^{1,2}$, Chew Kew Hong ${ }^{1}$, Mohamed \\ Zamrud Zainal $^{3}$
}

\author{
${ }^{1}$ Universiti Teknologi PETRONAS, 32610 Seri Iskandar, Perak \\ ${ }^{2}$ Universiti Teknologi Malaysia, 81310 Skudai, Johor; \\ ${ }^{3}$ Halliburton, Hassi Messaoud, 16, DZ, 30500 Algeria \\ *Corresponding author.nabilla.aziz@utp.edu.my
}

\begin{abstract}
Teamwork is a crucial soft skill that need to be instilled to the undergraduates from Petroleum Engineering course in order to address the 10th and 12th Program Outcome outlined by the Engineering Accreditation Council for Malaysia higher education institution. Teamwork is beneficial to the students in order to build their self-confidence, exchange their opinions, develop critical and creative thinking to improve their learning process and serves as a life-long learning skill that could be utilized in the oil and gas industry and other engineering sectors. The key objective of this study is to investigate the teamwork in capstone project which is a summative assessment to address the affective domains to produce well rounded graduate. This study aims to examine the impact of teamwork in the process of project-based learning in the compulsory capstone course for final year students to their individual performance. Its assessment was claimed to be designed based on capstone project requirements by the Engineering Accreditation Council. The capstone course design is a project-based learning (PBL) approach as it is designed for group activity that will go on for two semesters. The research measured for the teamwork performance in four dimensions which is Working with Others, Planning and Organising, Effectiveness under Stress and Commitment to job. Additionally, this study deployed a quantitative method through a set of questionnaires. The design capstone course is unable to accommodate or evaluate excel teams of Teamwork performance and it addresses heavily on the cognitive domain through their Coursework performance. These findings could be an eye-opener to lecturers in designing appropriate student-centred learning approaches.
\end{abstract}

Keywords: project-based learning, teamwork performance, final year students, capstone project

\section{INTRODUCTION}

Capstone projects are amongst the criteria required in academic engineering for implementation of integrative subjects and the teaching of key expertise that are difficult to deliver in the normal lectured course [17]. Capstone design projects may be completed individually or in a team of group depending on the course program relevant. Since teamwork has been seen as a imaginative and reflective opportunity to teach the young engineer how to be and how competent it can be in such a real world industry. Most courses in capstone design planning require students to achieve a design project within a team. The Field Development Plan (FDP) course is the capstone project for the final year students in Petroleum Engineering Department. It is designed based on the requirements set forth for capstone project by the Engineering Accreditation Council (Engineering Accreditation Council, 2017). The capstone project would be a complex engineering concern involving an interpretation of the discipline's core knowledge as well as the students' skills that had been established throughout their learning. The FDP project aims to produce a feasible solution taking into consideration the technical, the economics and the sustainability aspects. For each FDP course, the student presentation and report are assessed on Week 7 and Week 14. Individual assessments are conducted throughout the course and at the end of the course.

The layout of the FDP course suits well to the projectbased learning approach, as it is designed for group activity that will last for two semesters. At the end of the course the final outcome will be a report and a presentation. It has clear timelines and milestones, where students will be measured as the work progresses [3]. The students are given an open ended project with more than one possible solutions, this was intended to simulate a real world production of a field development plan.

The implementation of the FDP courses in the Petroleum Engineering Department had faced some challenges. The students' performance was less than satisfactory as indicated by the fairly "low" assessment marks given by both internal and external examiners for the project final products, i.e. the presentation and the report. Some of 
comments given by the examiners were poor integration among group members, low quality report and lack of interests. The students' performances were inconsistent between the FDP1 and the FDP2, and their performances also varied from batch to batch.

This research will assess the application of the projectbased learning approach on the FDP course delivery to identify any gaps, and to propose suitable interventions in order to improve the students learning and hence the course learning outcome. The study will look, in particular, at how by providing conducive environment for students to develop their teamwork skill would contribute towards students' learning experience and the course learning outcomes. This study, using a questionnaire survey, deployed a quantitative research method and is required to evaluate their team member according to the question given.

\section{LITERATURE REVIEW}

\subsection{Problem based learning}

The project-based learning originated from the ideology of pedagogy which postulated that the individuals learn best through their experiences and overcoming the real-world problems. This involved students working in small groups and taking control of their own learning as enablers with the lecturer [8]. Many researchers have reported the positive effects of well implemented PBL in higher institutions such as improving the student collaborative skills, engagement, critical thinking and problem solving skills [9]; [1] and [18]; and [12].

The project-based learning is a learning model that structures complex tasks based on real-world issues which require students to develop, solve problems, make a decision and investigate problems [8]. Project-based learning has several advantageous such as affecting positively student knowledge contents, developing soft skills (e.g. collaboration, critical thinking and problem solving), as well as increasing student motivation and engagement [9]. These benefits conclude the requirement for the lecturer to facilitate the organising of the projectbased learning framework and the students to established and direct the goal and time management of the problem. [15] explained that project-based learning is usually accompanied by subject courses (e.g. mathematics, physics, etc. in engineering) and it requires the student to manage the time, the resources, the task, and the role differentiation. There are variations in the project-based learning models proposed by various researchers. [14] mentioned there were three general project-based learning models which are project exercise, project component, and project orientation. [7] put project-based learning into two categories: project oriented studies which was applied in individual courses and project organized curriculum which was applied throughout curriculum.
[7] explained that project oriented study involved small projects within individual courses progressing to a final year project. The small projects were usually correlated within the same subject with traditional methods of teaching. These projects focused mainly on applying and incorporating prior knowledge. The small projects may be carried out as individuals or small groups. The project management tool designed makes use through projects as the organizing framework for the entire curriculum, reducing subject-oriented courses. The students were split into small teams, and they would have project teachers working as mentors and advisors. Throughout the course that can last for a couple of weeks or a whole year, the activities were undertaken. [7] also mentioned that in Engineering Department of Aalborg University in Denmark, the completely project organized curriculum did not exist yet and the closest programs made up to $75 \%$ of the project organized curriculum.

[5] mentioned that he captured the PBL students satisfactory from questionnaire with results of student considered it as a challenging course but respond well as a transition to post-university employment. [5] showed the importance of capstone project in Geology Departments of Purdue University. The capstone project focused on past course knowledge usage, written and oral presentation skills, real world problem identification, team work skills, and working under tight deadlines. Redirecting the students in preferred direction without neglecting student autonomy is another important aspect of project-based learning.

\subsection{Teamwork}

In a cooperative environment, teamwork is a small group working together to accomplish similar team goals by sharing their thoughts and perspectives [16]. Team members must be able to adapt by debate rather than individually tailored behaviours to the cooperative in a team.

In order to successfully prepare engineering student in real working environment, the undergraduate student must be able to develop their soft skills. An engineer is must be possess on scientific skill and non-scientific skills such as know the limitation, gain new knowledge, great teamwork and communication skills with others to be able solved problem regarding engineering issues. This valuable attitude can be gain from teamwork activities [6]. In short, teamwork has a positive influence on team performance and team satisfaction if team members knows how to interact with each other.

To overcome any difficulties regarding teamwork are confidence, well communication and productive leadership. The following points are crucial benefit regarding the competence and efficiency of teamwork to build up an efficient teamwork without any others negative factors. 
1. Trust among all team members.

2. Learning how to give commitment to make decisions and plans of action.

3. Effective leadership with well-defined roles among team member.

4. Focusing on achieving collective data.

5. Well prepared to engage in team to contribute an ideas.

6. Professional performance evaluation of team members and recognition for outstanding work.

\section{METHODOLOGY}

This study examined the relationship of teamwork through peer review evaluation and the coursework performance of the final year students in an engineering capstone project. The questionnaire consists of respondent profile, based on their group number and the names of their members and to rate their members based on four criteria which are Working with Others, Planning and Organizing, Effectiveness under Stress and Commitment to job. Their coursework marks are obtained to compare with the peer review evaluation. The marks for coursework and peer review of each team members are averaged in to team marks, to correlate the performance in team basis.

The creation of team is self-choice which the students gathered their members to create a group of 5 to 6 members for 28 weeks commitment on the capstone project. The capstone project require fundamentals from several core subjects in the Petroleum Engineering course. The outcome of the course is to produce and present a technical plan of the complex case study in the oil and gas field given to them. The course addresses the Engineering Accreditation Council (EAC) for cognitive and affective domains through several Program Outcomes. Individual and team formative assessments are conducted throughout the course and at the end of the course.

The statements are being arranged in the orders of all four criteria, by keying in their team member name and to rate them accordingly. The respondents are required to rate 4 statements, by providing their opinion on the statement through a Likert-scale composite reflected in statements. Each statement for each criterion, is orderly arranged and have difference in intensity of the response towards the criteria. The statements are ranked from high marks of 5 for Option number I until 1 mark for Option number V.

The survey is to measure the teamwork performance of the final year student towards Project-based learning, which on the other hand, assist educators to improvise the capstone lesson plan.

The participants are final year undergraduate students from Petroleum Engineering, of different batches, one in September 2018 and the other is January 2019. The participants for the survey are 75 students in January 2019 and 100 students in September 2018. The group of students are required to participate in the evaluation, in order to evaluate their team member's interest and involvement, on the other hand, self-assess their own interest and involvement to the capstone project. The set of questions is as displayed in Appendix.

\section{RESULTS AND DISCUSSION}

A total of 175 respondents from final year undergraduate engineering course have answered the Teamwork assessment through peer review evaluation. The peer review was deployed during week 28 which is end of the semester. The individual Teamwork marks and the individual Coursework marks were averaged based on the two components in order to obtain the average marks of the team. Plot and analysis were done based on team marks rather than individual to evaluate the project-based learning on team basis. The discussion will deliberate on the result of two batch which are September 2018 and January 2019. The following are the analysis:
i. Mean Comparison between Coursework and Teamwork
ii. Grade Difference between Coursework and Teamwork
iii. Teamwork Competencies Rating

\subsection{Mean Comparison between Coursework and Teamwork}

There are 20 groups in September 2018 and 14 groups in January 2019 batch. The mean, variance and standard deviation were calculated to gain an insight on the data points distribution. The measurement of data points between Coursework and Teamwork based on team performance is shown in Table 1 .

Table 1 Team Average Marks in coursework and teamwork for September 2018 and January 2019.

\begin{tabular}{|c|c|c|c|c|c|c|}
\hline $\begin{array}{c}\text { Group } \\
\text { Count (N) }\end{array}$ & Assessment & Mean & Minimum & Maximum & Variance & $\begin{array}{c}\text { Standard } \\
\text { deviation }\end{array}$ \\
\hline 20 & Coursework & 78.52 & 70.90 & 87.56 & 22.15 & 4.71 \\
\hline
\end{tabular}




\begin{tabular}{|c|c|c|c|c|c|c|}
\hline $\begin{array}{c}\text { (September } \\
\text { 2018) }\end{array}$ & Teamwork & 82.87 & 70.5 & 100 & 72.95 & 8.54 \\
\hline
\end{tabular}

\begin{tabular}{|c|c|c|c|c|c|c|}
\hline $\begin{array}{c}\text { Group } \\
\text { Count } \\
(\mathbf{N})\end{array}$ & Assessment & Mean & Minimum & Maximum & Variance & $\begin{array}{c}\text { Standard } \\
\text { deviation }\end{array}$ \\
\hline $\begin{array}{c}14 \\
(\text { January } \\
2019)\end{array}$ & Coursework & 74.23 & 60.85 & 85.17 & 45.72 & 6.76 \\
\cline { 2 - 7 } & Teamwork & 83.82 & 64.79 & 96.5 & 88.69 & 9.42 \\
\hline
\end{tabular}
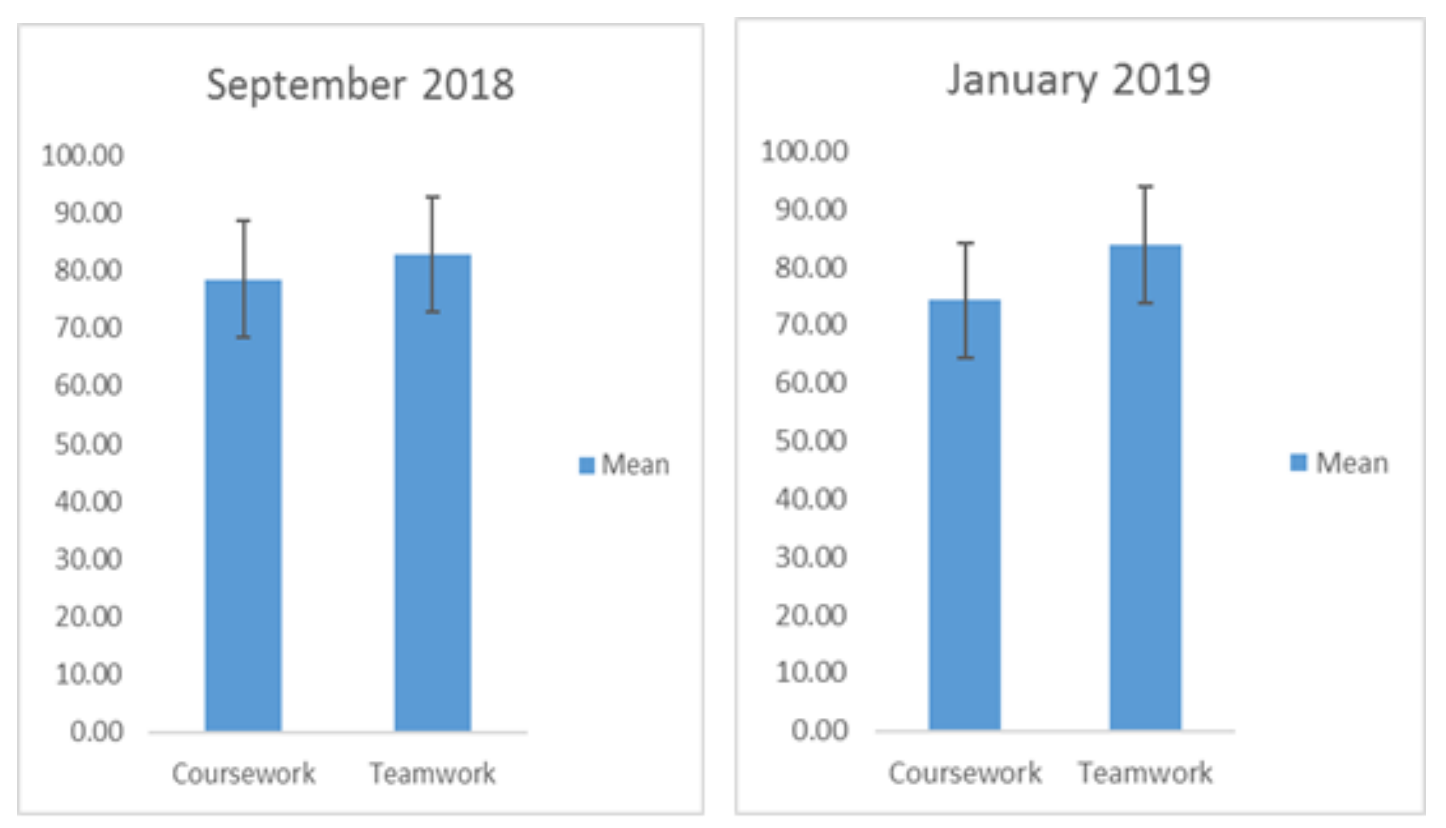

Figure 1: Team Average Marks in coursework and teamwork for September 2018 and January 2019. 
The standard deviation value showed less than 10 for both semester data points. The spread of data point for Teamwork is higher compared to Coursework, which indicate that the Teamwork result is showing wider spread of group marks from the mean marks for both semesters. This indicate that the students evaluated their team members for each criterion in the peer review rubric with precaution. The minimum and maximum Coursework and Teamwork marks for each respective semester showed similarity and consistent trend. A clear trend discrepancy is observed in Teamwork assessment for January 2019 between the minimum mark and the mean mark. The student individual performance influences the large difference from highest mark to lowest mark. This may indicate the presence of less performed individual which can be reflected from the mean marks which is very far from the minimum marks. There are three groups

\subsection{Grade Difference between Coursework and Teamwork}

The team marks for both Coursework and Teamwork were converted into percentage and being labelled based on grading system of A (85-100), A- (80-84), $\mathrm{B}+$ (75-79), $\mathrm{B}$ (65-74) and $\mathrm{C}+$ (60-64). The Teamwork and Coursework were compared to check the grade difference in order to observe the relationship of both performance.

For September 2018, there are $45 \%$ obtained same grade for both performance of Teamwork and Coursework. A portion of $20 \%$ of the teams gained one grade difference and the remaining $35 \%$ obtained two grade difference. This is equivalent to 7 teams having two grade difference which is alarming and reflecting that the assessment of the capstone course is not addressing the measurement of affective domain which is $75 \%$ mapped to the course learning outcome. For January 2019, the smallest percentage which is 21 $\%$ of the teams having the same grade for both performances and $29 \%$ of the teams obtained one grade difference between the two results. However, a majority of $50 \%$ showed two grade difference between coursework and teamwork results. Most of the teams evaluated high marks for teamwork, but unable to perform in their coursework which the weightage of the assessment is towards the cognitive domain. The groups did not manage to gain similar grades for their Coursework, probably due to the course lesson plan and course delivery of the capstone which is highly influenced on the cognitive domains or another possible factor would be lack of supervision by the team's supervisor on their capstone project work. This draws an assumption to the January 2019 batch, which majority of the team consist of cohesive members with strong team motivation, which brings to another analysis in $\mathbf{4 . 3}$ on the specific competencies that lead to high Teamwork marks. On another hand, only one team showed 2 grade difference of opposite items which is an average B grade for Teamwork, but average A grade for their coursework. which their average coursework is less than 70. It is clearly shown the same team scored lowest marks for Coursework and Teamwork. Therefore, the performance of the team in terms of teamwork is crucial in order to gain a better performance in their coursework.

The T-test value were calculated for both semesters. The significant difference between Coursework and Teamwork marks for September 2018 is 0.06 , whereas T-test value for January 2019 is 0.01 . If the T-test equals to 0 of both Teamwork and Coursework it will lead to a null hypothesis, however an absolute value was shown, which indicate that there is a significant difference between the marks and slightly increase in level of null hypothesis. However, the overall observed difference is less than 0.1 of the size of the variability between the marks. 


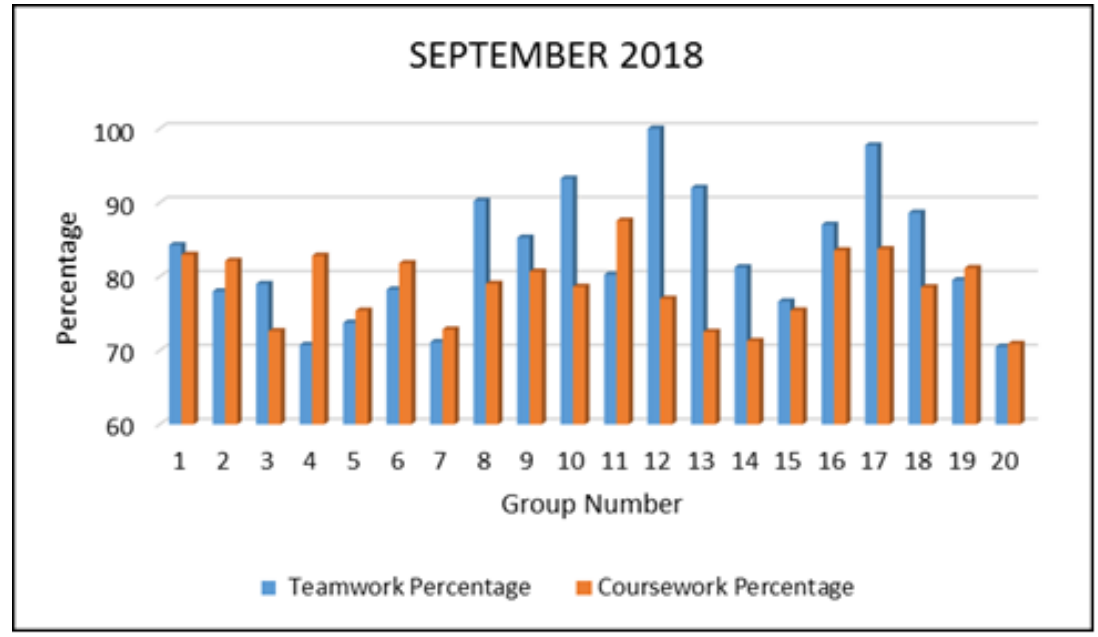

Figure 2: Performance based on group for September 2018

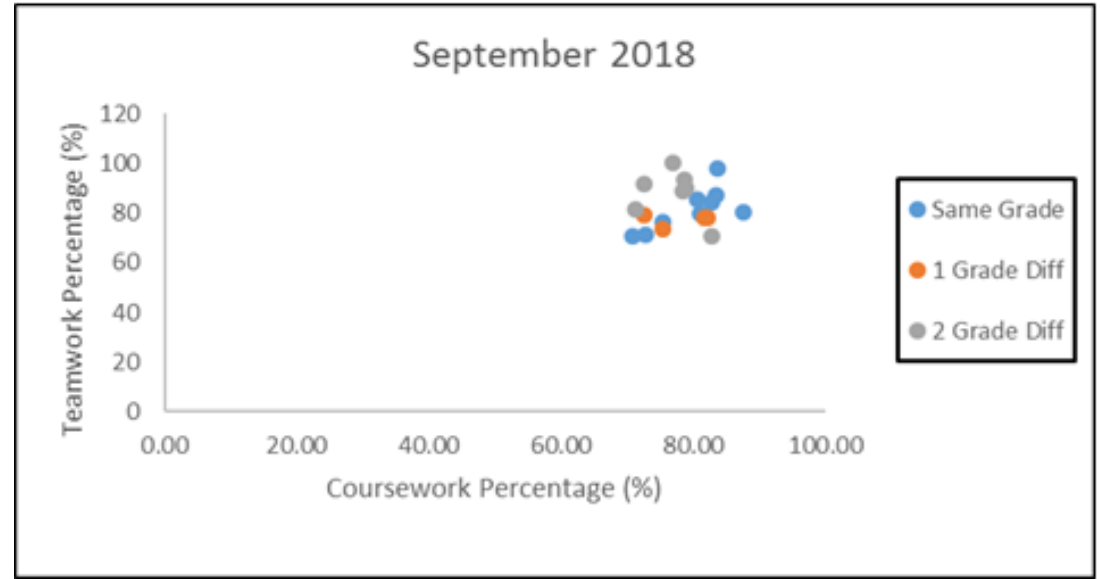

Figure 3 Plots on grade difference between Teamwork and Coursework for September 2018.

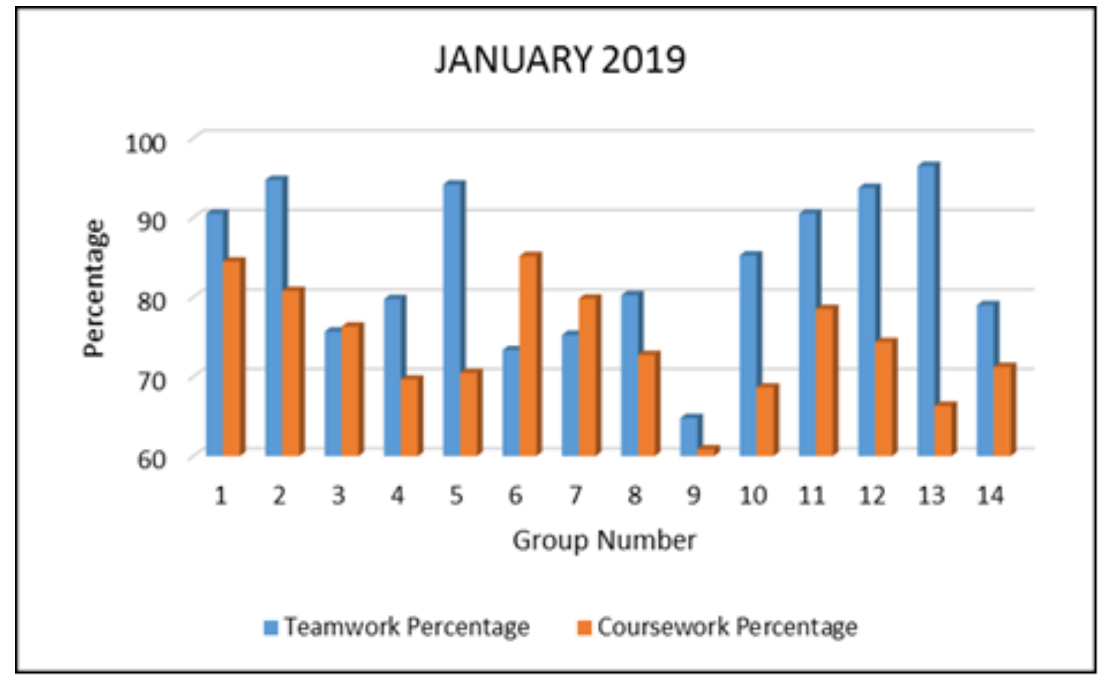

Figure 4 Performance based on group for January 2019. 


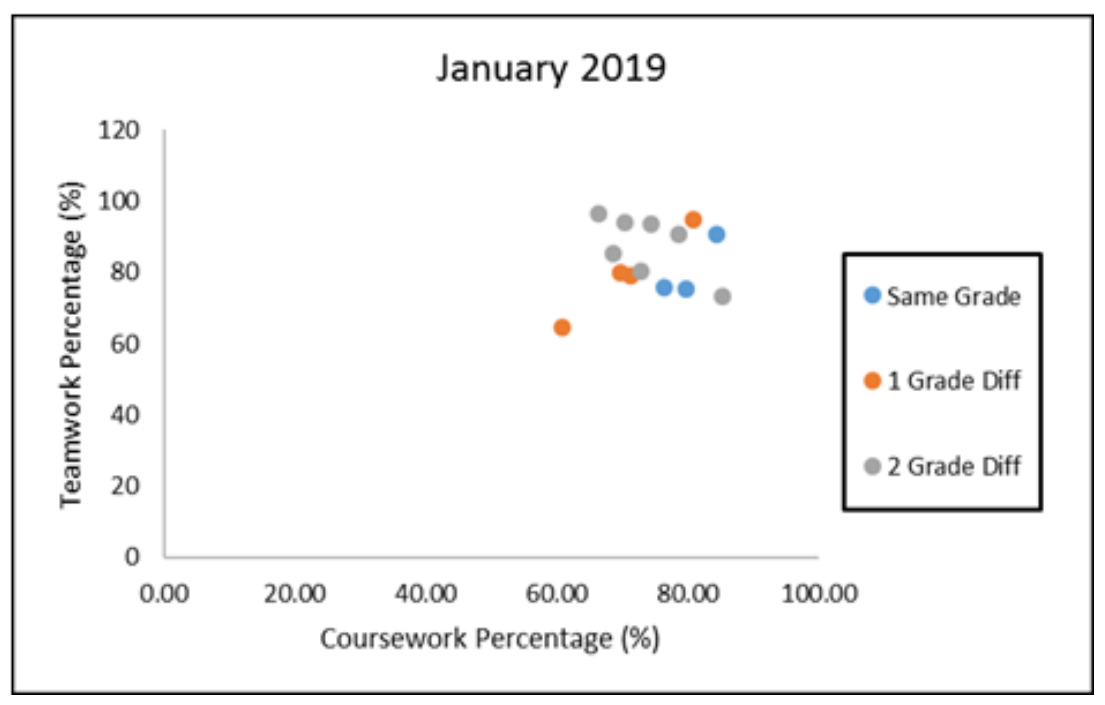

Figure 5 Plots on grade difference between Teamwork and Coursework for January 2019.

\subsection{Evaluation based on Teamwork \\ Components}

The teamwork component are discussed based on four criteria, which are the Working with Others, Planning and

Organising, Effectiveness under Stress and Commitment to Job.

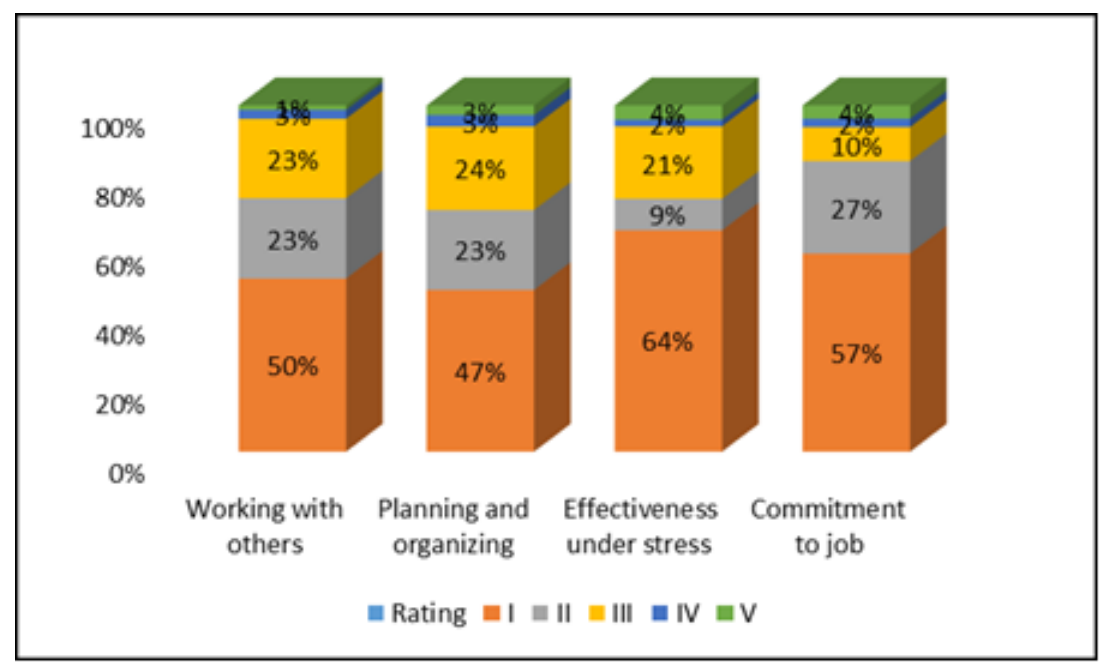

Figure 6 Distribution of Teamwork Competency based on Frequency of Evaluation for September 2018. 


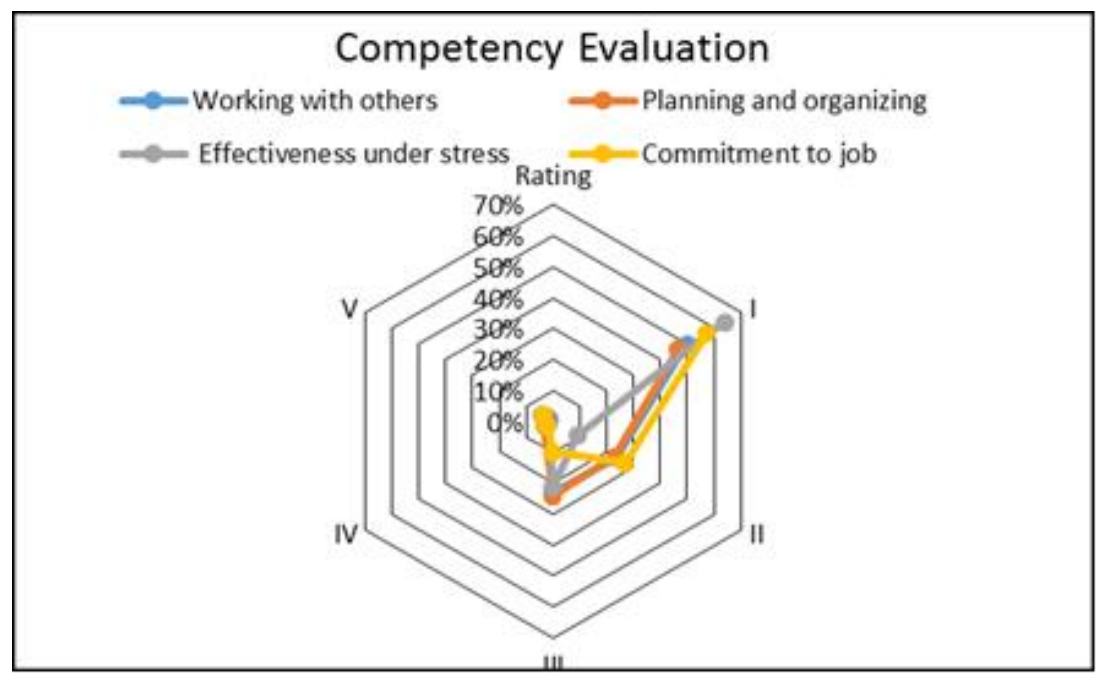

Figure 7 Radar Chart on the Comparison of Teamwork Competency Frequency for September 2018.

Rating I showed a record of 46-65\% response for the overall Teamwork competencies by the students of September 2018 batch. The result displayed half of the class could not acquire excellent teamwork competencies for their groups. There is a significant number of ratings for II and III in each competency, which indicate the members of the team rated satisfactory and good evaluation among them. The poor ratings of Rating IV and $\mathrm{V}$ is less than $6 \%$ of the whole class which leads to a frequency of 24 ratings that received negative statements for their Teamwork competencies. The number of low ratings was further investigated, and a portion of it was voted for three members in Group 2, 4 and 7. This led to poor team dynamics, as only two members in the team received good ratings.

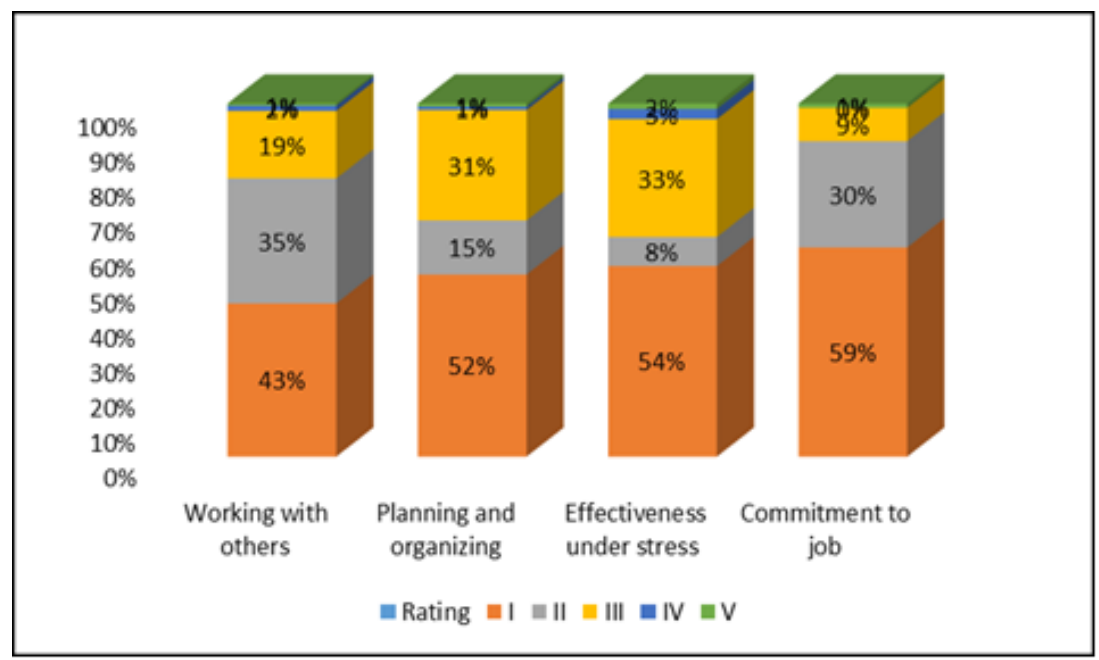

Figure 8 Distribution of Teamwork Rating based on Frequency of Evaluation for January 2019. 


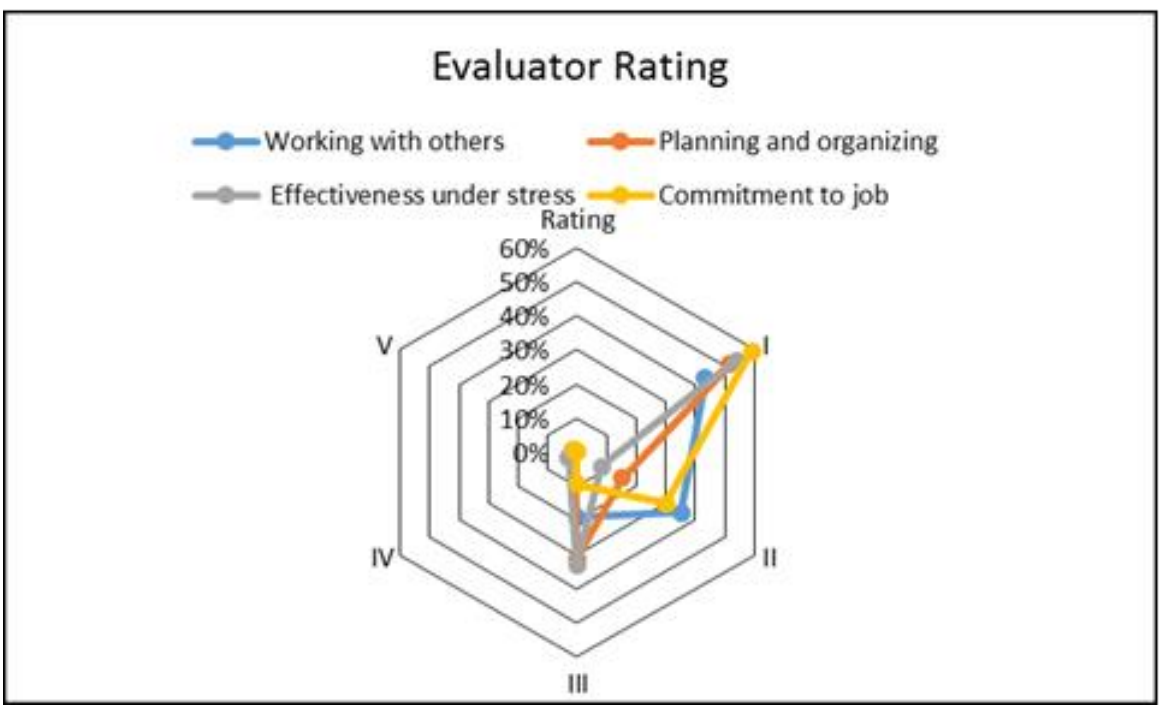

Figure 9 Distribution of Teamwork Competency based on Frequency of Evaluation for January 2019.

On another hand, the overall result for January 2019 showed a good track of teamwork performance which the negative statements are rated for less than $5 \%$ for overall rating IV and V. This reflects 14 frequency ratings for 14 members who received the negative rating that belongs to different group. Majority of the members are good in Working with others, Planning tasks, Handling Stress and Commit to the Task. The overall record showed positive team dynamics and enhances the learning experience for the course.

\section{CONCLUSION}

Addressing the cognitive and affective domains in capstone course are crucial in developing a well-rounded graduate. The ability of the students to evaluate their peers showed their maturity and awareness on the importance of teamwork in order to successfully deliver the project. The variation of team marks for teamwork showed that there is a need in intervention during the 28 weeks for teamwork module in order to develop responsibility of the student as a member working in the team, to deliver the project outcomes. The consistent trend of large difference between maximum and minimum marks for Teamwork in the course indicate that there is a large gap of teamwork performance between teams which is highly unlikely to reflect a well-rounded graduate attribute.

The cohesiveness shown by the January 2019 batch have displayed good to excellent marks for their Teamwork performance, however, they did not manage to gain good grades for their Coursework. The design capstone course is unable to accommodate or evaluate excel teams of Teamwork performance and it addresses heavily on the cognitive domain through their Coursework performance. This require a quality improvement to the capstone course as the number of course learning outcome mapped to cognitive domain is only one, whereas the course learning outcomes mapped to affective domains are three items. This led to the need of intervention by placing a scaffolding for team development or a team supervision that is able to monitor and improvise the Teamwork competencies and to be reflected in their Coursework marks.

Therefore, in order to produce a graduate with a good teamwork attribute, these findings could be an eye-opener to lecturers in designing appropriate student-centered learning approaches. Design of the capstone formative assessment should be tailored to include a portion of affective-domain in order to perform better in the coursework that will enhance the students' learning experience in project-based, while catering an integrated technical knowledge.

\section{ACKNOWLEDGMENT}

The paper is supported by the Center of Teaching and Learning CeTAL, under Scholarship of Teaching and Learning (SoTL) grant number: 0152AA-A88. Authors would like to express their appreciation to the final year respondents in Universiti Teknologi PETRONAS for their participation and time in doing the Peer Evaluation. 


\section{REFERENCES}

[1] Brush, T., \& Saye, J. (2008). The effects of multimedia-supported problem-based inquiry on student engagement, empathy, and assumptions about history. Interdisciplinary Journal of Problem-Based Learning, 2(1), 4.

[2] Clausen, T. (1998). Project Work as an Integrating and Revenue-Making Tool.

[3] Donnelly, R., \& Fitzmaurice, M. (2005). Collaborative project-based learning and problem-based learning in higher education: a consideration of tutor and student role in learner-focused strategies.

[4] Engineering Accreditation Council (EAC) Malaysia. (2017). Engineering program accreditation manual 2017.

[5] Harbor, J. M. (2000). A capstone course in environmental geosciences. Journal of Geoscience Education, 48(5), 617-623.

[6] Halim, M. A., Buniyamin, N., Imazawa, A., Naoe, N., \& Ito, M. (2014, December). The role of Final Year Project and Capstone Project in undergraduate engineering education in Malaysia and Japan. In 2014 IEEE 6th Conference on Engineering Education (ICEED) (pp. 1-6). IEEE.

[7] Heitmann, G. (1996). Project-oriented study and project-organized curricula: A brief review of intentions and solutions. European Journal of Engineering Education, 21(2), 121-131.

[8] Thomas, J. W. (2000). A review of research on project-based learning.

[9] Krajcik, J., Blumenfeld, P. C., Marx, R. W., Bass, K. M., Fredricks, J., \& Soloway, E. (1998). Inquiry in project-based science classrooms: Initial attempts by middle school students. Journal of the Learning Sciences, 7(3-4), 313-350.

[10] Kokotsaki, D., Menzies, V., \& Wiggins, A. (2016). Project-based learning: A review of the literature. Improving schools, 19(3), 267-277.

[11] Mills, J. E., \& Treagust, D. F. (2003). Engineering education-Is problem-based or project-based learning the answer. Australasian journal of engineering education, 3(2), 2-16.
[12] Moalosi, R., Molokwane, S., \& Mothibedi, G. (2017). Using a design-orientated project to attain graduate attributes. Design and Technology Education: An International Journal, 17(1).

[13] McAlpine, I., \& Allen, B. (2007, December). Designing for active learning online with learning design templates. In ICT: Providing choices for learners and learning. Proceedings ascilite Singapore 2007.

[14] Morgan, A. (1983). Theoretical aspects of projectbased learning in higher education. British Journal of Educational Technology, 14(1), 66-78.

[15] Perrenet, J. C., Bouhuijs, P. A. J., \& Smits, J. G. M. M. (2000). The suitability of problem-based learning for engineering education: theory and practice. Teaching in higher education, 5(3), 345-358.

[16] Sanyal, S., \& Hisam, M. W. (2018). The impact of teamwork on work performance of employees: A study of faculty members in Dhofar University. IOSR Journal of Business and Management, 20(3), 15-22.

[17] Viswanathan, S. (2017). Implementation of Effective Capstone Projects in Undergraduate Manufacturing Design Engineering Program. American Journal of Engineering Education, 8(1), 45-60. 


\section{Appendix}

Teamwork Competencies

Competency 1: Working with others

\begin{tabular}{ll}
\hline No. & Options \\
\hline I & $\begin{array}{l}\text { Initiates and cultivates key contacts. Uses } \\
\text { tact and diplomacy. Gets unpopular things } \\
\text { done }\end{array}$ \\
II & $\begin{array}{l}\text { Receptive to other ideas. Always makes a } \\
\text { contribution and cooperates }\end{array}$ \\
III & $\begin{array}{l}\text { Makes and maintains workable relationships } \\
\text { with others }\end{array}$ \\
IV & $\begin{array}{l}\text { Sometimes fails to share ideas to gain } \\
\text { support }\end{array}$ \\
V & $\begin{array}{l}\text { Impatient listener. Does not consider } \\
\text { people's opinions. Loses their interest and } \\
\text { support }\end{array}$
\end{tabular}

Competency 2: Planning and organizing

\begin{tabular}{|c|c|}
\hline No. & Options \\
\hline I & $\begin{array}{l}\text { Always on top of things and in control. } \\
\text { "Panics" handled smoothly }\end{array}$ \\
\hline II & $\begin{array}{l}\text { Carefully plans so that support is available } \\
\text { when needed }\end{array}$ \\
\hline \multirow{4}{*}{$\begin{array}{l}\text { III } \\
\text { IV } \\
\text { V }\end{array}$} & Organises work to keep productively occupied \\
\hline & Does not prioritise. Spends too much time on \\
\hline & nonessential items \\
\hline & $\begin{array}{l}\text { Does not plan ahead. Always waits to the last } \\
\text { minute. Frequently misses deadlines }\end{array}$ \\
\hline
\end{tabular}

Competency 3: Effectiveness under stress

\begin{tabular}{ll}
\hline No. & Options \\
I & $\begin{array}{l}\text { Raises Game. Smoothly produces high quality } \\
\text { work to meet each new and existing deadline }\end{array}$ \\
II & $\begin{array}{l}\text { When a crises occurs, drops everything and } \\
\text { produces high quality work }\end{array}$ \\
III & $\begin{array}{l}\text { Stays calm during hectic periods and maintains } \\
\text { steady output }\end{array}$ \\
IV & $\begin{array}{l}\text { Keeps work flowing smoothly in normal } \\
\text { situations but loses it when pressure mounts }\end{array}$ \\
V & $\begin{array}{l}\text { Easily flustered when given more than one } \\
\text { assignment to do }\end{array}$ \\
\hline
\end{tabular}

Competency 4: Commitment to job

\begin{tabular}{ll}
\hline No. & Options \\
\hline I & $\begin{array}{l}\text { Eagerly seeks new assignments and challenges. } \\
\text { Pursues development activities in own time. }\end{array}$ \\
II & $\begin{array}{l}\text { Very attentive to responsibilities. Discourages } \\
\text { casual conversation when there's work to be } \\
\text { done }\end{array}$ \\
III & $\begin{array}{l}\text { Works dependably on regular assignments but } \\
\text { does not take on extra work }\end{array}$ \\
IV & $\begin{array}{l}\text { Does not devote time to develop new job skills. } \\
\text { V }\end{array}$ \\
& $\begin{array}{l}\text { Frequently tardy or absent for reasons others } \\
\text { consider frivolous. Outside interests more } \\
\text { important. }\end{array}$ \\
\hline
\end{tabular}

